\title{
The theory of lie: from the sophists to socrates
}

\author{
Evgeny Nesmeyanov ${ }^{1 *}$, Yulia Petrova $^{2}$, Nazhavat Abueva $^{3}$, and Aliya Ismailova $^{3}$ \\ ${ }^{1}$ Don State Technical University, 344006, Rostov-on-Don, Russia. \\ ${ }^{2}$ Rostov State University of Economics, 344002, Rostov-on-Don, Russia. \\ ${ }^{3}$ Dagestan State Technical University, 367015, Makhachkala, Russia.
}

\begin{abstract}
The last third of the 20th century and the first decade of the 21 st century show the growth of scientific and especially, scientificpromotional papers on the problems of the particularities and forms of existence of deception and lie in European culture and social life. The concepts have emerged, proving the necessity and value of certain forms of lies for the preservation of the state, the family, and the implementation of the real practice of human communication: the existence of such activities as diplomacy, business, art and others. In some psychological and pedagogical papers define the idea of the importance of lie and deception for the development of the child's intellectual abilities, and the success of the adult in the society. With almost unlimited amount of such literature of different theoretical levels, synthesizing the «philosophical and cultural studies of lies and deception» are much less. The papers devoted to the emergence of the first attempts of the theoretical explanation of the established practice of lying and deceiving with the help of rationally constructed theoretical constructions are not enough. This article is an attempt to fill this gap partially.
\end{abstract}

The authors reflect the origin of the concept of value and the necessity of lies in the teachings of the «first sophists» from the $5^{\text {th }}-$ to the beginning of the $6^{\text {th }}$ centuries B.C., about the person, a new understanding of the main goal and the meaning of life of a free citizen - as the achievement of political supremacy. Protogor, Prodik, Gorgiy, Thrasymakh, Kallikil and others raised the problem of educating a leader who has, besides a number of volitional and moral qualities, the ability to manipulate people's consciousness. To change the beliefs and values of citizens on «needed» for the prosperity of a democratic state.

The authors show, based on the analysis of the ancient texts of the sophists and the Socratic dialogues, the origins of the first attempt of theoretical understanding of lies in the political life of the Athenian state. Emphasis has been placed on the interpretation of the Russian philosopher - A.F. Losev's method, which is based on the irony of Socrates as the first form of «lying-irony» and a methodological method of rational knowledge. Movement to the truth and to the «common good» at any cost, even at the cost of deception - is a paradox, shown by Losev. Relying on the study of this phenomenon, the authors conclude that Socrates had "improved" the lie both syntactically, lexically, and methodologically. Thus, traditionally-revival view of Socrates as a «Christian before Christ», «Saint Socrates»

\footnotetext{
*Corresponding author: nesmeyanoff.e@yandex.ru
} 
and even «Christ before Christ» loses its meaning, since Christ and lies are absolutely incompatible.

During the writing of the article, the authors used systematic-structural, historical and genetic research methods.

The sophists - these «teachers of Greece» in IV BC put forward a series of original ideas. One of them is justifying values and the need of lie in policy and public life. There are no attempts of a theoretical explanation of the phenomenon of lie and deception until sophists.

The logic of sophists' school in this matter is sufficiently transparent; and their theory is undoubtedly practical for their time. If we schematically and abstractly present the submission of the sophists about their contemporary political and state life, we get the following picture.

The model of the Greek state is Athens - the most free, cultural state in the world known to the sophists. All other states are «flawed» or just wild, «barbaric». The most important criterion for the superiority of Athens over other countries is the existence of civil life. A «citizen» differs from a «subject» in the level of freedom and dignity towards the state power. Civil life fully manifests itself only in a democracy. The most important quality of democracy - is the election of all public authorities from top to bottom. Democratic elections are presented in inevitably competitive (agonal) manner. In general, the life of a citizen of a democratic state is always associated with the struggle for political power and superiority over other citizens. There is no genuine citizenship outside political life. A citizen is always and «directly» involved in politics. From these, all understandable provisions, the sophists' novation (for the $4^{\text {th }}$ century BC) follows. Public positions should not be held by aristocrats, or people with connections, or wealthy citizens; but citizens who are specially prepared for the fulfilment of state functions.

Protagoras, Gorgias, Callicles, Thrasymachus, Paul, and other sophists put forward the idea of «educating» statesmen. Preparation for state activity includes a certain level of education, and knowledge about the laws of economics, military strategy and tactics, geography, religious and artistic life of nations, etc. and so forth. The most important thing is the education of certain moral and strong-willed qualities of the future politician. And it is the starting point where the sophists raise the question of the value and necessity of lies and deception. The main goal and meaning of life of a free citizen is a political career. «Civic valor», superiority over other contenders for the most important leadership positions, this is what should bring politician to the top of a career.

Werner Jäger insightfully remarks: «Maintenance the democratic order in the state ... becomes dependent on the leader's personality. In fact, it was a problem of democracy ... the goal of the educational movement, accomplished by the sophists ... in the formation of the leader [13, P. 339].

But what qualities of a leader can be raised? What to teach? Genius, intuition, energy, cannot be raised. These qualities are recognized as a gift of nature, or the Gods of Olympus. But the ability to manipulate the minds of people, replacing their beliefs, their values by the «needed» of politician - this can be taught. The ability to speak - is the ability to convince, it can taught by rhetoric.

Rhetoric - is the skill of «skilled speech making black to white» [10, P. 491], the ability to lie, speaking in more simple way. Rhetoric provides more than other knowledge an opportunity for the future superiority of a statesman. The politician does not need a fundamental science, he is not a theorist. $\mathrm{He}-$ is a practitioner whose knowledge is simultaneously similar to craft and art. Political decisions are unique. A true politician is not just a skilled orator (and liar), he has the experience of foresight, will and determination, and certain intuition. That is why the politician is similar to the artist - the creator of the unique pieces of art. This idea will be repeated by Machiavelli and Bismarck 
and many other great politicians who will formulate the essence of politics as an «art of the possible.»

How, then, does politician relate to morality? Human morality, according to the sophists, does not contain any eternal, universal laws. Morality - is always the fruit of simple agreement between people, it is «conventional». A person can recognize as a moral law, what is beneficial to him «here» and «now», and change the moral law to another when it is convenient for him. Sophist Kallikl recognizes the moral law «the right of the strength.» Only the strength will protect against human injustice, he believed. «The best for me is the same thing as the strength» [11, P. 489], and the strongest «those who are intelligent in public affairs» [10, P. 491], [11, P. 489].

The sophists unequivocally determine the value of lies as an important tool of political struggle and the path to success. Using a lie can change the values of people without armed violence. In this, is the highest prowess of a politician - «prowess of the word,» which is higher than the "prowess of the sword.» Lie is not only useful, it has a positive effect on a person, giving him courage and integrity of character, «courage and not relaxation of the soul» (Gorgy 491 b). Thus, a lie is not only justified by policy, but also morally as «the path to justice», the achievement of state and personal welfare in a democratic society.

These ideas of the sophists are rightly criticized by Socrates. However, the great philosopher, who learned from the sophists in his youth, uses a different, more subtle form of deception and false irony.

The irony of Socrates as a weapon in the fight against an opponent for the truth is periodically raised as a historical and philosophical problem and an important contribution to European culture as a whole (including modern culture) [12]. However, most researchers note the ambiguous attitude of the contemporaries of Socrates to his irony. Already Aristophanes, during the life of Socrates, in his comedy «The Clouds» through the mouth of Strepsiădes, says that «the ironic is a liar» [3, P. 443-451].

Aristotle in «Nicomachean Ethics» considers irony as a form of deception (IV 1127 a 2'2) [4]. Tough, with Roman directness, the irony of Socrates was defined by M.T. Cicero as «duplicity» and «a way of pretending», «what is called irony by Greeks» [8]. Unlike sophists, who allowed deception as the norm in a political struggle, Socrates believed that the irony is possible in the struggle for truth, for the values of a person's spiritual life. It turns out that the truth can be achieved using the «modification of a lie» - irony. Of course, no one disputes the noble thoughts of Socrates, but ... Hegel draws attention to this and writes that «Irony (from the side) is something untrue» [7, P. 45].This idea is picked up by A. F. Losev, defining the irony of Socrates as «a deception and idle talk ... only from the outside» [2, P. 77-78]. What does it mean? Deception is deception from any side, and «untruthful» is synonymous with «false». It is clear that the achievements of Socrates in the struggle for his convictions and his heroic death outweigh any shortcomings of his methodology, but some doubts remain ... and, apparently, A. F. Losev does not just call Socrates - «creepy man» and «antique decadent» [5, P. 105-109]. As a result: starting with the Sophists and Socrates, a lie acts as the norm and value of the political life of a democratic society (sophists) and the method (irony) of the struggle for truth (Socrates).

In ancient Greece, IV. BC, in democratic Athens, the idea of lies and deception was born, conceived as a necessity for the achievement of the wealth and freedom of the state and civil society. The theory of the sophists revives in the new conditions of the late $20^{\text {th }}$ early $21^{\text {st }}$ centuries, but without references to the original sources. As for Socrates and his modifications of lie-irony, the situation is more complicated. Here it is necessary to turn to the works of the Russian-Soviet philosopher A. F. Losev.

With all the enthusiastic and positive characteristics of Socrates' doctrine, his methods of philosophizing, his significance for world culture and philosophy of A. F. Losev (probably the only one after Nietzsche), all gives an unexpectedly sharp and even shocking 
definition of Socrates' personality. Characteristic of Socrates - a man so unexpectedly tough, which raises the question: «Is there some unspoken idea, hidden agenda?» Judge for yourself. On the one hand, Losev characterized Socrates as «a genius of philosophy» his activity is «a turning point in the entire history of the human spirit» [2, P. 51]. Again, «Socrates was the first who wanted to understand the life» [2, P. 52]. His «irony aimed to change life for the better» [1, P. 466]. Highest approval! Suddenly, other characteristics emerge: «the general appearance (of Socrates) is mysterious and scary ...», «somehow particularly sarcastically good-natured, sarcastically good-natured ...», «he took revenge on his good-nature, he knew something deep and secret about every single person and he knew especially bad things about him» [2, P. 79]; <...> «Priap's grimaces»; «Terribly intelligent», «he developed this sophistic erotic, priapic wisdom», «Socrates was at once terrible and ridiculous», «Socrates ... is the first antique decadent», "savagely intelligent decadent». Socrates - «a genius clown who knows something that people do not know» [2, P. 80-82]

The disciple of Socrates, Diogenes, who has with him (Socrates) an «organic relationship», Losev defines as a «monster» [2, P. 83]. And the direct disciples of Socrates — the Cyrenaics - for the most part «set free sexual intercourse as the highest form of goodness and beauty.»

The question arises, if these disciples are «immediate», and have «organic relationship» with Socrates, that is, how to call the teacher of «monsters», also a monster? And, finally, the final chord of the characteristics of Socrates by Losev - «a terrible person.»

About whom are these definitions? Are they suitable only for Socrates? This suggests some comparison with later literary characters. Goethe, for example: «I am... a part of the power which does good without a number, desiring evil for everything» («Faust»). Who else uses irony to deny common values? Is in the case of Socrates - the values of the Athenian polis? At the same time, constantly repeating that he «knows that he knows nothing.» Who destroys, but does not create, hiding his knowledge, without revealing his positions directly and honestly? Who is this «spirit, always accustomed to deny,» who says: «I am not omniscient ... I am only tempted?» («Faust»).

Losev calls him a «genius clown», and Mikhail Bulgakov in the novel «The Master and Margarita» - «Mr. Artist». The picture of Socrates' personal identity in its negative part is well depicted in another literary figure «ironic creature», which is well known by Losev. In the novel by F.M. Dostoevsky «The Brothers Karamazov» the devil characterizes himself in the night conversation with Ivan Karamazov as follows: «I love earthly realism ...», «I am no strange to human»; «Philosophize with noble purposes»; «I love the truth and sincerely wish well»; «I wish a man to be exalted in the spirit of divine titanic pride»; «Hourly by winning already beyond borders the nature by my will science» [6, P. 80-83]. Ivan Karamazov calls him a jester (by Losev - a «brilliant clown»). As far as the image of Socrates by Losev is inspired by literary reminiscences, we will never know. But there is one, more substantial basis for understanding the assessments of Socrates by Losev, which lies outside the literary imagery. It is in the field of philosophical methodology.

This reason is in the characteristic signs of philosophical irony, introduced by Socrates into rational knowledge.

Socrates uses a certain method in a dispute, in discussions, which will later be called «irony.» Nowhere Socrates himself calls his doctrine «irony.» Why so? For him, «irony» is what exists in the practice of real life. In this case - is the practice of tax evasion. Socrates' «self-conceit» takes place in a completely different sphere - in the struggle for truth. Breaking the arguments and theoretical constructions of his opponents, Socrates never proclaims the truth. Moreover, he explicitly states that he does not know the truth, but his opponents, the sophists, also do not know the truth, although they present their judgments as ultimate truth. This position of Socrates is widely represented in antiquity. 
According to one practice where irony is clearly identified with lies, deception, and manipulation with the consciousness of people in the political life of the Athenian state. The sophists (with whom Socrates is genetically connected) directly and unequivocally speak of the need for a politician to be able to lie for seizing and holding political power. In the dialogues of Plato, the sophists assert that the authority is achieved mainly by force, but also by «skillfully constructed by speech that makes white from black». At the same time, the sophist Callicles says that he sees the highest practical political «justice» (Plato, 1991), in the use of lies in order to seize the authority. In another words, lie in politics is the path to justice. Here is a paradox.

The irony of Socrates is a way to deceive the opponent by instilling a false idea of his intellectual powers, giving him the opportunity to relax, feel his superiority (in fact imaginary) and deliver a decisive blow. For this, Socrates is «cunning», «pretending.» Speaking harshly, Socrates is constantly lying.

Socrates admits a lie in the form of irony for the development of philosophical knowledge, spiritual development of the individual. Of course, you can talk about the «good purposes», which at the same time pursues Socrates. But the fact is that Socrates deliberately uses «lie - irony» as a methodological device for rational knowledge! It turns out that the struggle of Socrates for the truth, true knowledge does not exclude methods that include elements of deception. Socrates goes to the truth at any cost, even at the cost of deception. Another paradox arises: the movement to the truth, and therefore to the «common good» (which Socrates tries to achieve), goes through deception.

In fact, Socrates perfected the lie syntactically, lexically and methodologically, and this «taste» of lie is never forgotten.

It will be relevant to turn to the works of the Russian-Soviet philosopher A. F. Losev (a Christian believer, an Orthodox monk) defines this aspect of the activities of Socrates as a «terrible», «eerie» and, if you like, frankly, «satanic» character trait. There is a very interesting text A. F. Losev, indirectly confirming such an understanding. Comparing ancient and romantic irony, Losev writes: «This is where «the Satanism» arises, which was to the romantics' heart ... that mixture of jokes, mockery, irony and at the same time flirting, posturing, scheming and virtuosic artistry» [1, p. 688].

Aleksey Fedorovich knows perfectly well the established philosophical and cultural tradition, starting with the humanists of the $15^{\text {th }}$ century, - to compare Socrates and Christ. Socrates - «Christ before Christ» or «Christian before Christ». Erasmus Roterodamus even called Socrates «Saint» and asked him to «pray for us». On the pages of his «History of Aesthetics», Losev quotes Søren Aabye Kierkegaard doctoral thesis, published in Munich in 1929 [2, P. 77]. And what was Kierkegaard's theology writing about in 1841? The thesis was called «On the concept of irony.With a constant eye on Socrates», where one of the questions Kierkegaard poses a problem, what was more - similarities or differences between Socrates and Christ? And he concludes that the comparison of God and man is the tragic mistake of humanists. A.F. Losev knows this job. And the monk Alexey Fedorovich Losev (Andronicus) - knows that a lie has never gone down from the mouth of Christ. The truths of Christ's doctrine were not accompanied by irony and other forms of lies. Falsehood and Christianity, falsehood and Christ are incompatible. Socrates cannot be «Christian before Christ», «Christ before Christ». He is only a «terrible person.» Maybe here we may find the explanation of the mystery of the characteristics of Socrates by Losev?

\section{References}

1. A. F. Losev, The history of ancient aesthetics, The results of the millennial development, 466, 688 (1994). 
2. A. F. Losev, The history of ancient aesthetics, Sophists, Socrates, Plato, 5, 77-78, 8082, (1969).

3. Aristophanes, Clouds, Selected Comedies, 443-451, (1974).

4. Aristotle, Works in 4 vol, (1983).

5. E. E. Nesmeyanov, Possible meanings of Socratic irony in the interpretation of A.F. Losev, HSS, 4, 105-109 (2012).

6. F. M. Dostoevsky, The Karamazov Brothers, Full composition of writings, 80-83, (1976).

7. G. V. F. Hegel, Lectures on the history of philosophy, 2, 45 (1994).

8. M. T. Cicero, Lucullus 5.15, (2004).

9. Plato, Plato Dialogues "Protagoras", "Gorgiy" (Collected Works, 1990).

10. Plato, Gorgiy, (Collected Works, 1990).

11. Plato, Protagoras (Collected Works, 1990).

12. V. O. Pigulevsky, Irony and fiction: from romanticism to postmodernism, (2002).

13. W. Y. Werner, Paydeyya, 339, (2001). 